\title{
The Contribution of Sugarcane Partnership for the Livelihood Structure and the Development of Rural Areas in Lampung Province of Indonesia
}

\author{
Asnani $^{1}$, Arya Hadi Dharmawan ${ }^{2}$, Bambang Juanda ${ }^{3}$, Dudung Darusman ${ }^{4}$ \\ ${ }^{1}$ Department of Sociology, Faculty of Social and Political Sciences, University of Lampung, Lampung, Indonesia \\ ${ }^{2}$ Department of Communication and Community Development Sciences, Faculty of Human Ecology, IPB University, Dramaga \\ Bogor, Indonesia \\ ${ }^{3}$ Department of Regional and Rural Development Planning, Faculty of Economics and Management, IPB University, Dramaga \\ Bogor, Indonesia \\ ${ }^{4}$ Department of Forestry Management, Faculty of Forestry, IPB University, Dramaga Bogor, Indonesia
}

\begin{abstract}
Sugarcane is a mainstay commodity crop as raw materials for sugar. Therefore, increasing domestic production through partnerships is an effort to suppress the high value of imports. The purposes of this study are to identify the farmer's household land use, to analyze the income structure and livelihood strategies, and then to conduct an economic dependency analysis on the sugarcane industry in relation to rural area development. The research method used a survey approach of 131 households and interviews with the head of village and the heads of farmer groups. For data analysis, descriptive statistics and analysis of farm income were used. The results show that farmers use land for sugarcane partnership with a choice of Kerjasama Operasional (KSO) or operational cooperation, the Independence (Mandiri), and Hutan Tanaman Industri (HTI) or industrial forest plantation partnership. The sources of livelihood structure of farmers are from non-sugarcane agriculture, sugarcane farming, Non-Timber Forest Products (HHNK), and non-farm. Engaging in sugarcane partnership is a new livelihood strategy for the rural communities surrounding the plantations with benefits that are affected by the area of owned land. While farmers who do not own land, they earn a living by becoming plantation laborers. Farmer involvement in sugarcane partnership contributes to the household income, the existence of uneven welfare, and the emergence of household economic dependence on sugarcane plantations. The sugarcane partnership is a source of income and an engine of rural economic growth; however, the realization of sustainable rural development has not yet emerged.
\end{abstract}

KEYWORDS: Economic Dependence, Livelihood, Rural Development, Sugarcane Partnership

\section{INTRODUCTION}

Sugar cane is a source of raw material for sugar, more than 500 years, sugar cane plantations have become a mainstay to meet Indonesia country needs [1]. In more detail, the world's oldest sugar factories in history are the sugar factory in Thailand which has been established since the 13th century, in Brazil since the 15th century, and in Indonesia which is estimated to have existed since the 16th century. Indonesia experienced its glory around 1930 when it exported 2.40 million tons of sugar [2].

Increasing sugarcane production is very important considering that the domestic sugar needs have not been fulfilled so that more than half of the sugar needs in Indonesia must be imported. The high demand for sugar can be seen from the results of predictions on the production, the volume of imports, and the consumption of sugar in Indonesia from 2017- 2021 [2].

Table 1. The Projection Results of Production, the Volume of Export and Import, and the Consumption of Sugar in Indonesia

\begin{tabular}{llll}
\hline Year & Production (Ton) & Import Volume (Ton) & Consumption (Ton) \\
\hline 2017 & 2.465 .450 & 2.604 .051 & 5.069 .501 \\
\hline 2018 & 2.440 .931 & 2.647 .270 & 5.088 .201 \\
\hline 2019 & 2.453 .647 & 2.691 .132 & 5.144 .779 \\
\hline 2020 & 2.466 .429 & 2.735 .796 & 5.202 .225 \\
\hline 2021 & 2.479 .277 & 2.781 .202 & 5.260 .479 \\
\hline Average growth (\%/year) & 0.14 & 1.66 & 0.93 \\
\hline
\end{tabular}

Source: Ministry of Agriculture 2017 


\section{International Journal of Current Science Research and Review}

ISSN: 2581-8341

Volume 04 Issue 07 July 2021

DOI: 10.47191/ijcsrr/V4-i7-08, Impact Factor: 5.825

IJCSRR@ 2021

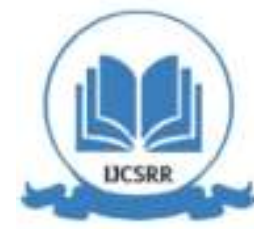

www.ijesrr.org

The production growth, the import volume, and the consumption continue to increase until 2021; however, the average growth in the import volume is higher at 1.66\%/year. This shows that Indonesia will increasingly depend on imported sugar to meet domestic needs. Meanwhile, the sugar consumption in Indonesia consists of household consumption and industrial consumption. The household sugar consumption decreases by an average of 1.30\%/year. In 2002, the consumption of sugar per capita was $9,203 \mathrm{~kg}$, and it decreased by $23.25 \%$ or to become at $7,467 \mathrm{~kg}$ in 2016 . Around $26 \%$ of Indonesia's sugar production is used for industrial purposes each year. Currently, sugarcane agroindustry activities continue to contribute to the agricultural sub-sector with plantation crops to GDP of 10.93 in the third quarter of 2017, and there is a trend of increasing land area and sugarcane production in 19672019 [2].

The sugar import policy is a short-term policy in meeting Indonesia's sugar needs; however, the government is trying to increase production and set self-sufficiency targets in sugar production through policies by on-farm and off-farm. The condition of national sugar stock is highly dependent on the supply of raw materials [3], therefore an intensification, extensification, and institutional approach are needed. In 2003, the expansion of the area began to gradually increase [4] and was predicted to continue to increase with the encouragement of the current government program, Tanah Objek Reforma Agraria (TORA) or Land for Agrarian Reform Objects, which will be identified in advance to the lands that become objects, such as forest land acquisition and abandoned land, and also identified subjects of beneficiaries of agrarian reform [5].

In Indonesia, Lampung province becomes a potential development area for dryland sugarcane [6]. In general, the existence of sugar cane plantations has an impact on economic, social and environmental aspects [7];[8];[9];[10];[11]. The sugar cane agroindustry and all of its derivatives have an impact on improving the economy of a region such as the expansion of production which has an impact on GDP, to be specific the employment and trade [8];[12]. This contribution is expected to encourage the development of the local area, so that it creates continuous social and economic welfare for the community.

The sugarcane agro-industry institution is also built to support the expansion of land through a partnership model between sugar factory and the local community with a contract [13], the capital and market certainty [14], the benefits for farmers through loans/credit [15], and economic actors which will have success if they cooperate [16]; however, there are also obstacles to the lack of transparent policies and mechanisms [17]. At the lowest level, partnerships affect the livelihood structure and the level of economic resilience of farm households [18].

The land use on a large scale of sugarcane commodity greatly influences the community to choose the type of plant commodities to be planted. Yet, this process is very slow and much influenced by socioeconomic factors [19]. Land conversion causes a shift in the location of agricultural activities and changes in the livelihoods and income of farm households [20], cost factors, benefits, and economic drivers that determine the will and determine the ability of farmers to invest in sustainable land management [21].

The changes in farmers' land use due to sugar factory activity on farmer's land will also affect the livelihood structure of farmers in rural areas. The concept of livelihood means all abilities, assets and activities needed to continue living (survival) [22]. The strategy to achieve this is conducted by engineering social and institutional infrastructure [23], states that the assets referred to in livelihood are natural, physical, human, financial and social, as well as how to access assets and use of assets through institutional patterns as individuals and households [24]. The positive economic impact caused by the pattern of the sugar cane partnership, affects the sugar cane partner farmers to have a strong relationship in their sources of income. The sustainable living is related to how much vulnerability and resilience ability are faced by an individual or household to shocks [25].

Another impact of the implementation of the organization is the dependency between parties in the institution/new institution in the sugarcane partnership, especially in the household economic dependency on sugar factory [26]. The community livelihood strategies based on economic rationality states with the assumption that farmers have bounded rationality, where in actual circumstances farmers are able to choose the best alternative; however, the available alternative choices are too narrow to have an impact on losses [24].

The sugarcane plantation zone in Waykanan Regency has 3 partnership models, namely the Kerjasama Operasional (KSO) Model, the Independent Model, and the Cooperation Model in rural area and Hutan Tanaman Industri (HTI) area that involves villagers inside and outside the forest area. The sustainability of the partnership model can be seen from its impact on the structure of the source of income of farm households involved in each village and forest location. Furthermore, the determination of the poverty line based on the world bank needs to be conducted at each of the partnership locations involved. 


\section{International Journal of Current Science Research and Review}

ISSN: 2581-8341

Volume 04 Issue 07 July 2021

DOI: 10.47191/ijcsrr/V4-i7-08, Impact Factor: 5.825

IJCSRR@ 2021

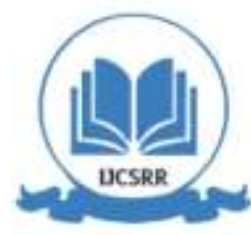

www.ijcsrr.org

Rural communities enter a phase of dependency with outsiders, systematically becoming laborers on their own land [27]. The studies of the community's agro-industry/plantation partnership, eventually, want to address the structural trap of backwardness experienced by villages in relation to the mechanism of household livelihood [23] which ultimately triggers dependence on external parties. As with the results of other studies related to the development of large plantations, sugarcane through partnerships is expected not only in terms of regional economic benefits, but also the maintenance of future socio-economic welfare of rural communities can be achieved [28].The partnership model is expected to be an engine of economic growth in Waykanan district so that it creates prosperity and sustainable development for rural communities. This research is interesting and different because it examines the structure of sugarcane partnership farmer household income and its relation to the economic dependence of sugarcane.

The purposes of this study are (1) to identify the land use cultivated by farmer households involved in partnerships, (2) to analyze the income structure and the strategies of household livelihood, (3) to analyze the economic dependence on the sugarcane industry in relation to rural area development.

\section{MATERIAL AND METHODS}

This research was conducted in May to December 2017 and from May to August 2018. The selection of research locations was conducted purposively, namely the subdistricts of Negara Batin, Pakuan Ratu and Bahuga in the Waykanan regency of Lampung Province and HTI Register 44 (forest code), with following considerations; 1) having a sugar cane partnership with sugar factory, 2) the proximity of the location of sugar factory as a marketing place for sugarcane that receives sugarcane harvest, and 3) having a land to partner with sugar factory and PT Inhutani. The villages chosen to be the location of the study were Negara Batin Subdistrict which consisted of Srimenanti Village, Mulya Negara Village, Karta Jaya Village, Batin Negara Village. Pakuan Ratu Subdistrict consists of: Ratu Negara Village, Kampung Negara Sakti Village, Gunung Waras Village. Bahuga Subdistrict is only one village which was chosen, namely Mesir Ilir Village.

The respondents in this study were the farmer households of the sugarcane partners (KSO, Mandiri, and HTI). The sampling method was conducted by using a simple random sampling method. The determination of the number of samples [29] was with the following formula:

$$
n=\frac{N Z^{2} S^{2}}{N d^{2}+Z^{2} S^{2}}
$$

Note:

$n \quad=$ number of samples

$N \quad=$ number of populations

$Z \quad=$ degree of trust $(95 \%=1,96)$

$S^{2} \quad=$ sample variation $(5 \%=0,05)$

$d \quad=$ degree of deviation $(5 \%=0,05)$

The samples per village were taken by proportional random sampling method. The details of the number of samples from each village were obtained using the following formula:

$$
n i=\frac{N i}{N} n
$$

Note:

$n i=$ number of $\mathrm{i}^{\text {th }}$ sample location

$\mathrm{Ni}=$ number of $\mathrm{i}^{\text {th }}$ farmer population

$N \quad=$ number of entire population of $\mathrm{i}^{\text {th }}$ partnership model

$n \quad=$ number of farmers sample of $\mathrm{i}^{\text {th }}$ partnership model

Table 2. Distribution of Research Samples

\begin{tabular}{lllllll}
\hline & $\mathrm{KSO}=700(\mathrm{~N}) *$ & & Mandiri=80 $(\mathrm{N}) * *$ & HTI=32 $(\mathrm{N}) * * *$ \\
\hline Location & $(\mathrm{Ni})$ & $(\mathrm{ni})$ & $(\mathrm{N})$ & $(\mathrm{n})$ & $(\mathrm{N})$ & $(\mathrm{n})$ \\
\hline Srimenanti & 96 & 12 & 4 & 2 & & \\
\hline Negara Mulya & 38 & 4 & 4 & 2 & & \\
\hline
\end{tabular}




\section{International Journal of Current Science Research and Review}

ISSN: 2581-8341

Volume 04 Issue 07 July 2021

DOI: 10.47191/ijcsrr/V4-i7-08, Impact Factor: 5.825

IJCSRR@ 2021

www.ijcsrr.org

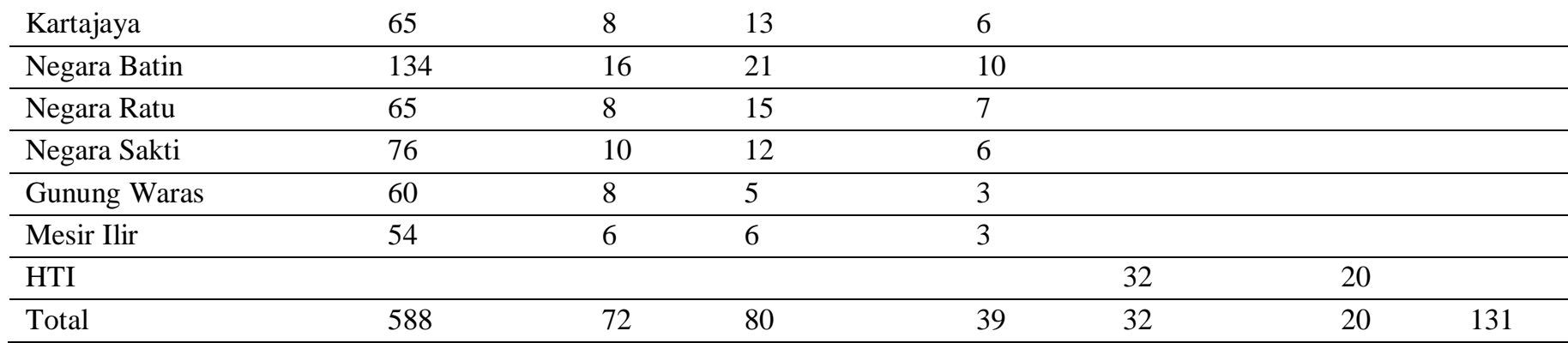

Source: * Interview with the head of the local village.

** Interview with the head of the Independent partnership group of the local village.

*** Annual Plans of a commercial company (PT. Inhutani V): there are 32 partnership groups with a varied number of members, in this study, it uses 1 respondent to represent each group.

Table 3. Research Data

\begin{tabular}{|c|c|c|c|}
\hline \multirow[t]{4}{*}{ Data Variable } & \multicolumn{3}{|l|}{ Objectives } \\
\hline & Land Use & Revenue & Sugarcane \\
\hline & & Structure & Economy \\
\hline & & & Dependence \\
\hline Identity of respondents & $\sqrt{ }$ & $\sqrt{ }$ & $\sqrt{ }$ \\
\hline The participation in sugarcane partnership (KSO, Mandiri, and HTI) & $\sqrt{ }$ & $\sqrt{ }$ & $\sqrt{ }$ \\
\hline Controlled land area $(\mathrm{Ha})$ & $\sqrt{ }$ & $\sqrt{ }$ & $\sqrt{ }$ \\
\hline Cultivated land area (Ha) & $\sqrt{ }$ & $\sqrt{ }$ & $\sqrt{ }$ \\
\hline Land partnerships area & $\sqrt{ }$ & $\sqrt{ }$ & $\sqrt{ }$ \\
\hline Agricultural commodities/types of cultivated plants & $\sqrt{ }$ & $\sqrt{ }$ & $\sqrt{ }$ \\
\hline Production costs per commodity (Rp) & & $\sqrt{ }$ & $\sqrt{ }$ \\
\hline Harvest yield per commodity $(\mathrm{Rp})$ & & $\sqrt{ }$ & $\sqrt{ }$ \\
\hline Income per commodity (Rp/Ha/year) & & $\sqrt{ }$ & $\sqrt{ }$ \\
\hline Non-timber forest product revenue (Rp) & & $\sqrt{ }$ & $\sqrt{ }$ \\
\hline Non-farm revenue $(\mathrm{Rp})$ & & $\sqrt{ }$ & $\sqrt{ }$ \\
\hline Sugarcane partnership income (Rp/Ha/Year) & & $\sqrt{ }$ & $\sqrt{ }$ \\
\hline Experienced vulnerability aspect & & $\sqrt{ }$ & \\
\hline Strategies to overcome vulnerabilties & & $\sqrt{ }$ & \\
\hline
\end{tabular}

The data used was primary data (tabel 3). Primary data collection was conducted by observation, in-depth interviews, and surveys of 131 farm households. The analysis of the data analysis used descriptive statistics. In objective 1 (land use), the survey data was calculated based on the area of cultivated land based on the commodity/types of plants and the types of partnership to be identified. In objective 2 (income structure), it used the analysis of farm income. In order to examine the sources of farm household income, the formula was used as follows:

$$
\pi=\mathrm{TR}-\mathrm{TC}
$$

Note:

$\begin{array}{ll}\pi & =\text { Farm income } \\ \mathrm{TR} & =\text { Total Revenue } \\ \mathrm{TC} & =\text { Total Cost }\end{array}$

In objective 3 (sugarcane economic dependency), it was analyzed by using the dependency quadrant. The quadrant in the Cartesian diagram was determined by the criteria for the source of income. 


\section{International Journal of Current Science Research and Review}

ISSN: 2581-8341

Volume 04 Issue 07 July 2021

DOI: 10.47191/ijcsrr/V4-i7-08, Impact Factor: 5.825

IJCSRR@ 2021

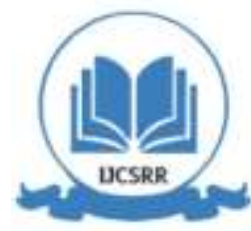

www.ijcsrr.org

\section{RESULTS AND DISCUSSION}

The Use of Agricultural Land

Sugar factories expanded the land using a sugar cane partnership scheme starting in 2011, involving communities who owned land and were willing to enter into a cooperation contract. The expansion of this land is conducted in order to guarantee an increase in local sugar production. Based on land use, the sugarcane partnership consists of 3 forms, namely KSO, Mandiri, and HTI. The KSO partnership pattern is that the farmer as the owner of the land surrenders his concession rights to sugar factory with compen sation for profit sharing after harvest (milled cover). The Independent Partnership Pattern, namely farmers' land, is collected and managed by a group coordinator, which is then sold to sugar factory. While, the HTI partnership pattern is the HTI area land which has been granted its concession rights by PT Inhutani to the community through groups. Through a group cooperation contract and its coordinator planting sugar cane in partnership with sugar factory, PT Inhutani gets a profit sharing of around 30\% from the sugarcane farming run by the group.

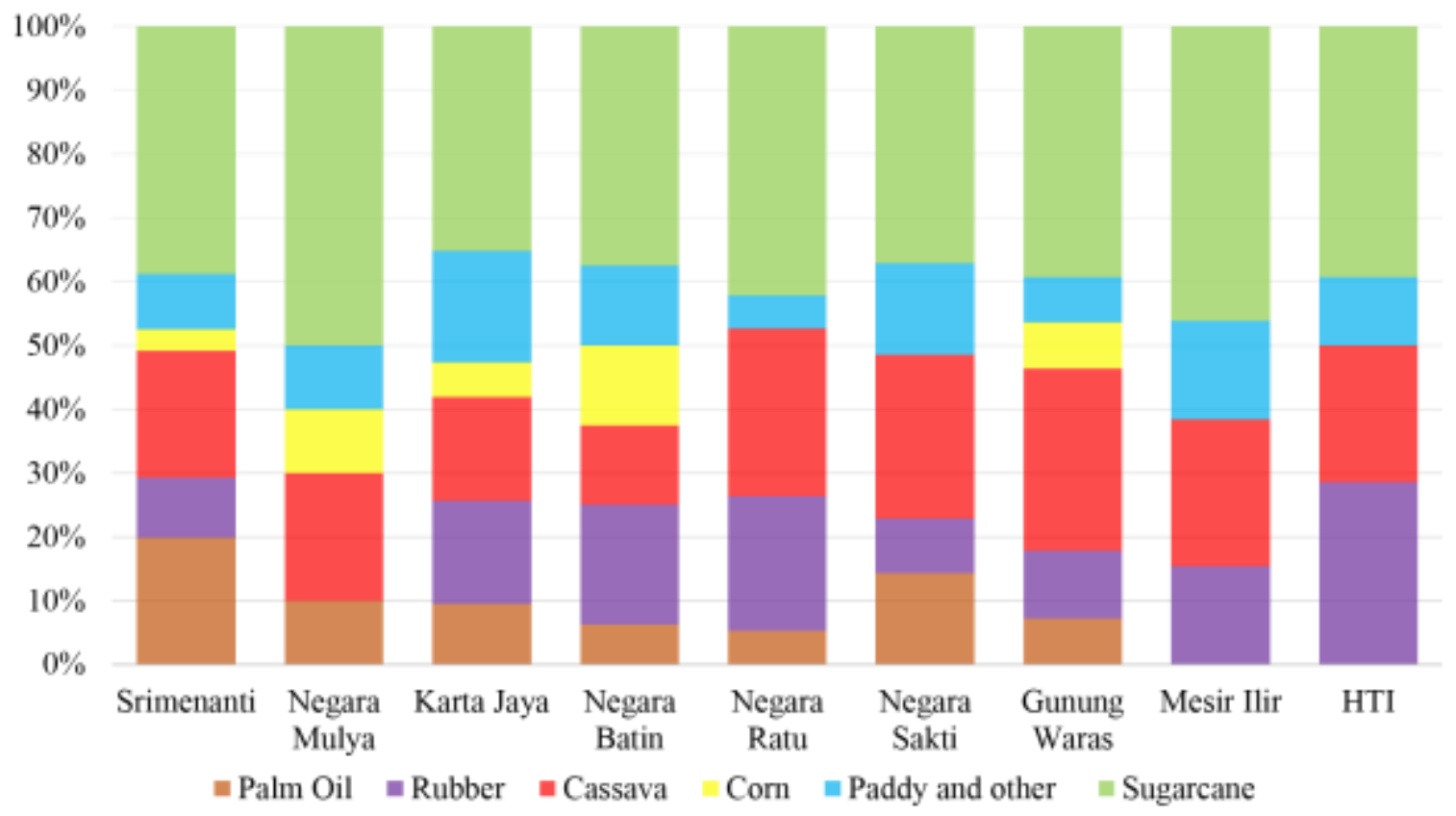

Figure 1. The Use of Agricultural Land Based on Land Use

Before the agricultural system was partnered, some farmers cultivated the land and some were in the form of thickets. For those who have the capital of the land, it is endeavored to plant seasonal crops such as cassava, corn, or paddy fields. For farmers who do not have the capital, the land is planted with a variety of tree crops such as timber and seasonal fruits that are agro-forestry. The need for firewood and a portion of household food depends on the shrub land.

In Figure 1, the agricultural system is distributed in the commodities of oil palm, rubber, cassava, corn, paddy and crops, and sugarcane. Sugarcane partnership appears dominant compared to other commodities in 9 villages and 1 HTI area. The farmers decide to cultivate agricultural crops only based on economic rationality. The rationale for farmers is that they will work their land with plants that are considered profitable at the time.

\section{Sugarcane Farmer Livelihoods Structure}

The land which is cultivated by the farmer itself is the support of household income, because the source of income from partners can be received at the end of the year. Therefore, farmers must use the remaining land to be a source of income, or work outside their land. The more land there will be, the more alternative sources of income for the community are. In contrast, the less and the depletion of land is held and cultivated, the less source of income for the community is. Therefore, they switch to non-farm income sources. 


\section{International Journal of Current Science Research and Review}

ISSN: 2581-8341

Volume 04 Issue 07 July 2021

DOI: 10.47191/ijcsrr/V4-i7-08, Impact Factor: 5.825

IJCSRR@ 2021

www.ijjcsrr.org

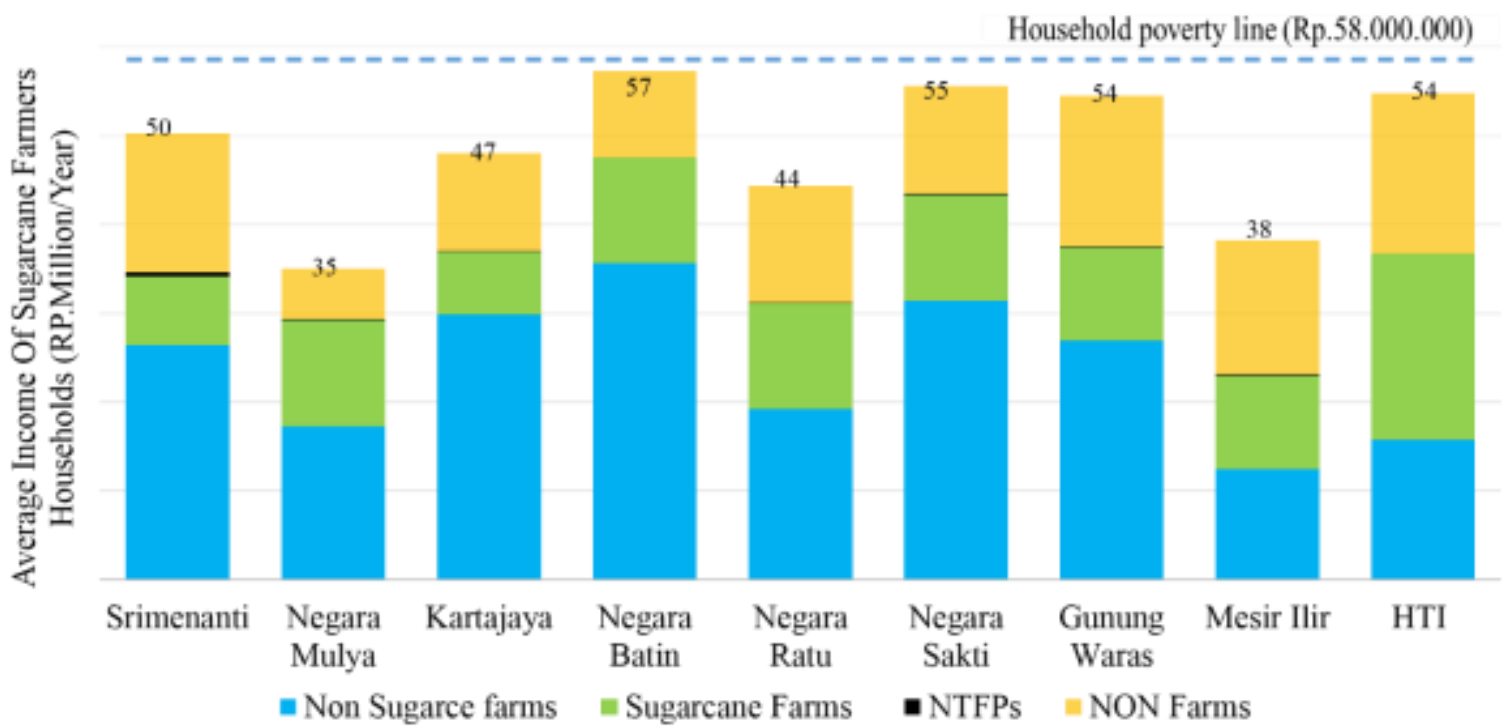

Figure 2. The Structure of Average Income of Sugarcane Farmers Households (from non-sugarcane agriculture sector, sugarcane agriculture sector, NTFPs, and non-farm sectors) in 8 Villages and 1 HTI area and poverty line according to the World Bank.

The sources of income from the non-sugarcane agriculture sector (oil palm, rubber, cassava, corn, paddy, livestock, and fisheries) appear greater than other sectors except for Mesir village and HTI. This shows that the source of income from agriculture has greatly contributed to the household economy of sugarcane farmers. While, sugarcane farming has a small influence on the household economy of farmers in each study location. This means that with the KSO and Independent partnership model, sugarcane farms cannot be a driver of household and regional economy. However, HTI partnership has a quite large influence of income sources compared to the non-sugarcane and non-farm agriculture sectors. The source of income from NTFPs is almost invisible, this is due to the lack of community access to forests.

According to the World Bank, the poverty indicator is seen through an income approach of USD \$2.00 per day or equivalent to $\operatorname{Rp} 27,136$ (the end of 2017, the exchange rate value of USD \$1.00 is equivalent to Rp 13,568). Meanwhile, the average number of household dependents is 6 people. Therefore, the poverty line based on the World Bank's average household income is Rp58,613,760. In Figure 2, it can be seen that all households in 8 villages and HTI areas are in the poverty line.

\section{Livelihood Strategy}

Some livelihood strategies in agricultural communities in rural areas include several types, namely 1) intensification and extensification of agriculture and 2) livelihood diversification [23]. There are two types of livelihood strategies for sugarcane partner farmers, even though the source of income from the partnership is relatively smaller than the non-sugarcane agriculture sector; however, farmers have a dependency on the partnership system. The farmers who have high dependency (HTI, Negara Mulya village, Negara Ratu village, Negara Batin village, and Negara Sakti village) have an extensification strategy by increasing land investment and expanding sugarcane. For some people who have capital loans, the opportunity to increase the area of controlled land is by investment and land expansion. Because, currently the land has a high economic value due to the competitive presence of the sugarcane factory, then some people are interested in investing in agricultural land. The land is very strategic to be partnered with, and it will become a struggle for those who have capital loans. This case will have an impact on the emergence of economic disparities in rural areas.

For people who control large land (more than 50 hectares per person), they can easily get capital loans or credit from sugar factory to work on the land. They will get a net income when finished or harvested the sugarcane. sugar factory will deduct the loan from the sale of sugarcane. Therefore, farmers who get credit loans must sell their crops to the sugar factory. This is also the farmer's strategy in cultivating their land, and strategy in maintaining the amount of raw material received. 


\section{International Journal of Current Science Research and Review}

ISSN: 2581-8341

Volume 04 Issue 07 July 2021

DOI: 10.47191/ijcsrr/V4-i7-08, Impact Factor: 5.825

IJCSRR@ 2021

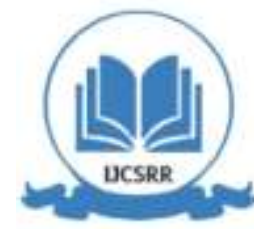

www.ijcsrr.org

The great pressure on land requirements from sugar factory and the economically advantageous opportunity that access to cultivate land in the HTI register 44 area have become an alternative source of income for the community through the partnership model. PT Inhutani through community empowerment in the forest through the partnership model develops into a legal access for the community to work on the HTI area. Although the partnership model offered by PT Inhutani, there are requirements and procedures; however, rationally farmers remain economically profitable.

While, the villages that have a low dependency on the sugarcane economy carry out strategies by intensifying land and diversifying other works (on farm). The agricultural intensification is conducted by the method of farming which is making fields that do not relocate. In these fields, farmers can grow food crops such as paddy and vegetables, which are usually in sufficient quantities for household consumption. When the situation is getting difficult, farmers usually sell their land little by little both to fellow farmers in the village or sold to sugar factory.

The availability of job opportunities as sugarcane plantation workers (day laborers) is an alternative for those who are no longer own land that is controlled. However, the income from being a plantation daily worker is only as a safety first to meet daily needs. Parents will find it difficult to facilitate their children's schooling to a higher level. Not to mention when they are sick or other family's needs, so that they have to leave the work, and there is no daily income.

\section{Economic Dependency}

The change in the agricultural system from traditional system to plantation system has changed the sources of income and the amount obtained by the community. This is because the loss of the concept of agriculture with agro-forestry becomes monoculture, thus treating the agricultural system becomes different. The sugarcane market is different from the commodity markets for oil palm, cassava, or rubber. The sugarcane market has a direct and in line relationship between farmers and sugar factory. In the Waykanan district, there is only one sugarcane factory which receives the sugarcane harvest, which is why sugar factory cooperates with the surrounding communities to partner. The principle of monopoly is very thick in the partnership and sugarcane plantation model. To guarantee raw materials, sugar factory provides business loans or capital credits for farmers who work on land of at least 50 hectares/person. With the capital loan and a guidance during the planting process, the farmer must sell the sugarcane to the sugar factory.

The loans are considered economically profitable because farmers can plant and harvest sugarcane without any capital constraints. In addition, market clarity and price benchmarks provided by sugarcane factories are also considered to be profitable, even though there is only one-way information regarding the price and yield of sugarcane as a measure of income received by farmers. The ease of getting capital loans, reaching the market, and the existence of 1 sugarcane market causes the farmers to depend on sugar factory. This is very risky for farmers in the future, as it is known that the political dynamics of the economy of large capital owners is very difficult to predict. Automatically, it will have an impact on the fate of rural development which is vulnerable to failure in the development due to the disrupted rural economic system caused by the dependence on global markets [30].

The difference in the average income of sugarcane partner farmer households based on the partnership model is very significant in the partnership model in HTI, which provides a higher average income compared to the Mandiri and KSO models (Figure 3). This is because the partner land in HTI is monopolized and managed by the group leader himself. Besides, there is a manipulation of group members that actually does not exist (opportunistic behavior). While, the Mandiri and KSO models have clear members, and its benefits are shared between land managers (the coordinator on Mandiri and sugar factory on KSO) and partner participants. The problem that occurs in both models is the occurrence of price transparency and the acquisition of profits between parties.

The dominant contribution of the agricultural sector is broadly in strengthening food security, poverty alleviation, job creation, and income distribution [31]. Basically, agro-industry development is expected to spur economic growth, as well as to be directed at increasing employment opportunities and farmers' incomes [27]. Likewise, the sugarcane plantation sub sector has contributed to the regional economy in Waykanan district. 


\section{International Journal of Current Science Research and Review}

ISSN: 2581-8341

Volume 04 Issue 07 July 2021

DOI: 10.47191/ijcsrr/V4-i7-08, Impact Factor: 5.825

IJCSRR@ 2021

www.ijesrr.org

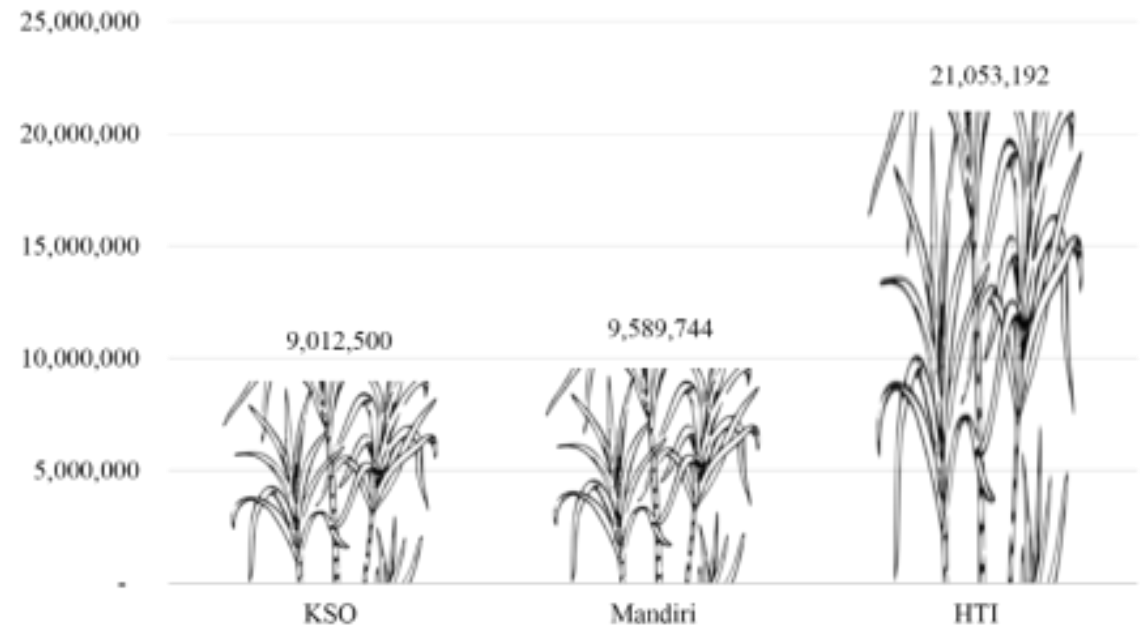

Figure 3. The Average Income of Farmer Households per Ha/year based on the Partnership Model

The development of the sugarcane agro-industry has an impact on the following sectors: an increase in the area of land, the contribution of income from sugarcane plantations to the regional economy, a growth in the number of workers employed, and especially an escalation in the number of people involved in partnerships. This pattern of cooperation provides opportunities for communities to empower their land, to become a productive land. States that economic growth will be severely limited by the availability of natural resources so that the supply of goods and services originating from natural resources cannot be carried out continuously. Sustainable agriculture (sustainable agriculture) is the implementation of the concept of sustainable development (sustainable development) in the agricultural sector [32]. Based on Figure 3, the implications of household economic dependency according to the distribution of research locations can be seen in the quadrant distribution (Figure 4).

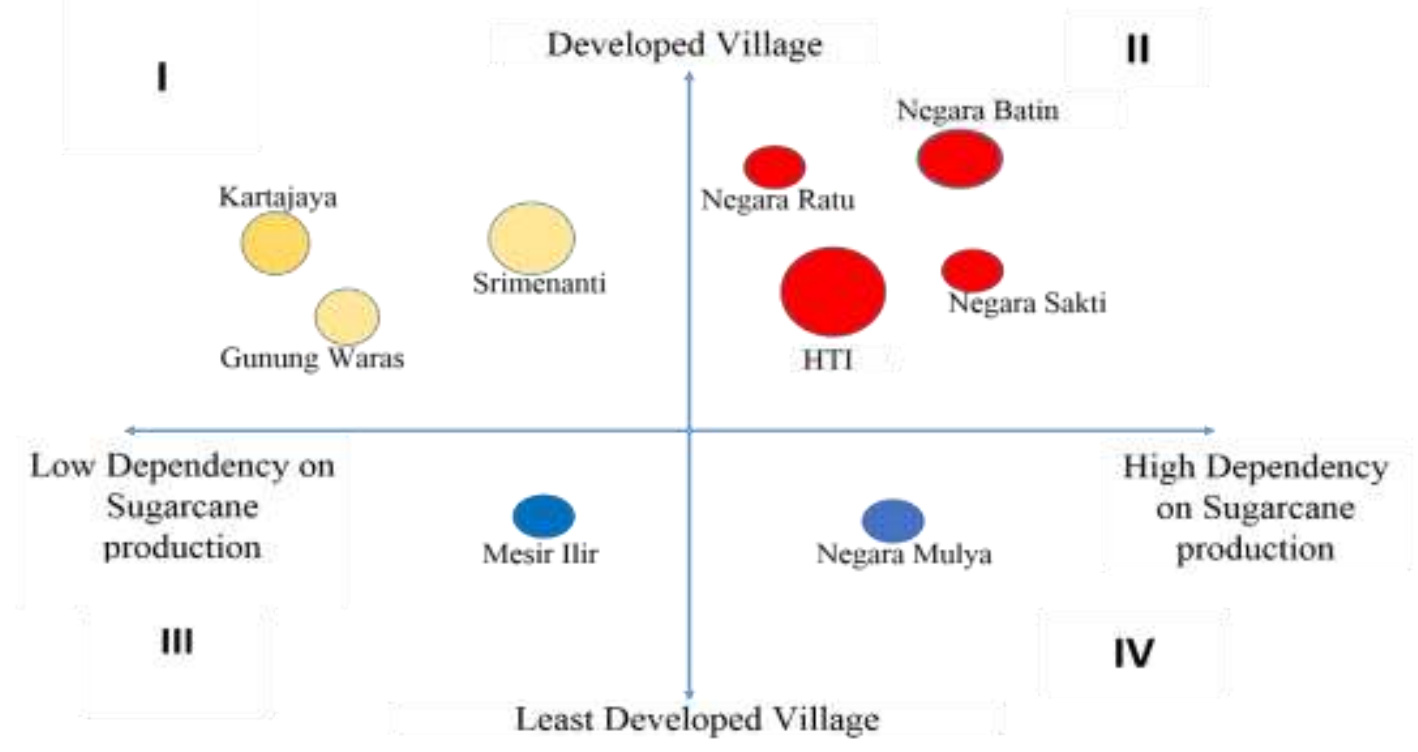

Figure 4. The quadrant economic dependence of sugarcane in the regional development

Based on the average approach of sugarcane farmer households (Figure 3), the least developed villages are those that have the average income of $\leq 40$ million per household per year, and the developed villages are those that have the average income of $\geq$ of 40 million. The high dependency category is the average income of the sugarcane sector $\geq 12$ million, and the low dependency category has the average income of the sugarcane sector $\leq 12$ million. The distribution of research locations is in the four quadrants, where in Quadrant I, there are 3 developed villages, and they have a low dependence on the sugarcane production. In Quadrant II, 


\section{International Journal of Current Science Research and Review}

ISSN: 2581-8341

Volume 04 Issue 07 July 2021

DOI: 10.47191/ijcsrr/V4-i7-08, Impact Factor: 5.825

IJCSRR@ 2021

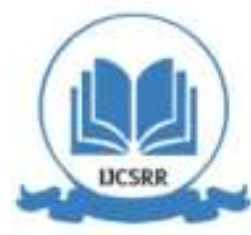

www.ijesrr.org

there are 3 villages and 1 HTI in the developed villages category, but they have a very high dependence on the sugarcane production. The shape of the big circle shows the level of its attachment is higher than the others. In Quadrant III, there is 1 least developed village that has a low dependence on the sugarcane production, meanwhile Quadrant IV has 1 least developed village that has a high dependency on the sugarcane production. The bigger the colored circle is, the greater the dependence has on the sugarcane production. The difference in color shows the different conditions in each quadrant.

In Quadrant II, it also shows that the welfare of rural communities is precisely due to high dependence. This is due to the fact that the villagers have large tracts of land to be partnered with sugar factory. The poor category is based on the Decree of the Minister of Rural Development and Disadvantaged Areas No. 126 of 2017 concerning the determination of priority villages for development of disadvantaged areas and transmigration.

The sugarcane plantations can increase the income and welfare of rural communities, so that it has implications for regional development. The sugarcane plantations can be the engine of regional economic growth; however, high dependence causes unsustainable regional development (it depends on companies). One of them is the sugarcane farm that can experience shortages of workers in the future due to the increasing number of mechanization [9].

\section{CONCLUSION}

The expansion of sugarcane plantation has put a pressure on the development of other crop commodities. The use of land for other types of commodities such as oil palm, rubber, cassava, corn, rice, and other crops is an alternative land use for sugarcane partnership farmers due to economic and subsistence benefits. The farmers following the sugarcane partnership are a new livelihood strategy for the rural communities surrounding the plantations with benefits that are affected by the area of land they have. Meanwhile, the farmers with large areas of land earn more income by cultivating their own land because of a capital loan/credit from a sugar factory. On the other side, the farmers who have narrow land get an annual income that is smaller than the land that is forged. While farmers who do not own land, they earn a living by becoming plantation laborers. The sources of income from the sugarcane agriculture sector contribute to the economic well-being of farm households; however, it cannot be a driver of regional economic growth. The partnership is a new livelihood strategy through land exploitation from capital loans from sugar factory and the emergence of new sources of non-farm income for those who do not own land. The partnership model in HTI is considered to be better in providing farmer household income; however, the problem of manipulation is a part of opportunistic behavior that signifies institutional weakness. The high dependence on the owners of capital loans causes a threat to regional and rural development in the future.

\section{REFERENCES}

1. Oliverio, J., Carmo, V., \& Gurgel, M. (2010). The DSM-Dedini sustainable mill: a new concept in designing complete sugarcane factories. Proc. Int. Soc. Sugar Cane Technol, 27, 1-34.

2. Ministry of Agriculture. (2017). Outlook Tebu: Komoditas pertanian, sub sektor perkebunan. Jakarta: ISSN : 1907-1507.

3. Ministry of Agriculture. (2015). Tree Corp Estate Statistics of Indonesia 2014-2016. Jakarta.

4. Ministry of Agriculture. (2013). Pedoman teknis perluasan areal perkebunan ta 2013. Direktorat Perluasan dan Pengelolaan Lahan Direktorat Jenderal Prasarana dan Sarana Pertanian Kementerian Pertanian. Jakarta.

5. Tigris, H.J. (2016). Kebijakan dan pelaksanaan landreform di era pemerintahan Jokowi-Jk. Rechtsvinding Media Pembinaan Hukum Nasional, 1-4.

6. Hani, E.S. (2016.) Stakeholder response to the development strategy of sugarcane dry land agriculture in east java. Agriculture and Agricultural Sciences Procidia, 9, 469-474.

7. Cardoso, T.F., Watanabe, M.D.B., Souza, A., Chagas, M.F., Cavalett, O., Morais, E.R., \& Cnpem, M. (2019). Biomass and bioenergy a regional approach to determine economic , environmental and social impacts of different sugarcane production systems in brazil. Biomass and Bioenergy, 120, 9-20.

8. Eduardo, C., Gilio, L. (2018). Expansion of the sugarcane industry and its effects on land use in sao paulo: analysis from 2000 through 2015. Land use policy, 76, 264-274. doi:10.1016/j.landusepol.2018.05.008

9. Prasara, A.J., \& Gheewala, S.H. (2015). Sustainability of sugarcane cultivation : case study of selected sites in. Journal of Cleaner Production, xxx, 1-10. 


\section{International Journal of Current Science Research and Review}

ISSN: 2581-8341

Volume 04 Issue 07 July 2021

DOI: 10.47191/ijcsrr/V4-i7-08, Impact Factor: 5.825

IJCSRR@ 2021

Www.ijcsrr.org

10. Sawaengsak, W., \& Gheewala, S.H. (2017). Analysis of social and socio-economic impacts of sugarcane production : A case study in Nakhon Ratchasima province of Thailand. Journal of Cleaner Production, 142, 1169-1175.

11. Moraes, M.A.F.D.de., Oliveira, F.C.R.de., \& Chavez, R.A.D. (2015). Socio-economic impacts of Brazilian sugar cane industry. Environmental Development, S2211-4645(15)00062-7. http://dx.doi.org/10.1016/j.envdev.2015.06.010

12. Fahrizal, Marimin, Purwanto, M.Y.J., Yani, M., \& Sumaryanto. (2014). Decision support model for sugarcane agroindustrial development (a case study at east nusa tenggara province). Teknologi Industri Pertanian, 24(3), 189-199.

13. Dessatria, A.N.U. (2013). Petani tebu (studi kasus : pabrik gula kebon agung kecamatan pakisaji kabupaten malang). Jurnal Ilmiah Mahasiswa FEB Universitas Brawijaya, 1(2).

14. Nurjayanti, E.D., \& Naim, S. (2014). Analisis kelayakan usahatani tebu (studi kasus petani tebu mitra PG. Pakis Baru di kecamatan Tayu kabupaten Pati). Mediagro, 10(1), 60-68.

15. Lestari, E.K., Fauzi, A., Hutagaol, M.P., \& Hidayat, A. (2015). Keuntungan petani tebu rakyat melalui kemitraan di kabupaten Jember. Buletin Tanaman Tembakau, Serat dan Minyak Indutri, 7(2), 79-89.

16. Yustika, A.E. (2013). Ekonomi kelembagaan paradigma, teori dan kebijakan. Jakarta: Erlangga.

17. West, J,J, \& Haug, R. (2017). The vulnerability and resilience of smallholder- inclusive agricultural investments in Tanzania. Journal of Eastern African Studies. 11(4), 670-691.

18. Budiyanti, I., \& Dharmawan, A.H., (2018). Strategi nafkah dan relasi sosial rumah tangga petani tebu (studi kasus: desa jenar, kecamatan jenar, sragen). Jurnal Sains Komunikasi dan Pengembangan Masyarakat (JSKPM), 2(1), $105-122$.

19. Gatto, M., Wollni, M., \& Qaim, M. (2015). Oil palm boom and land-use dynamics in Indonesia: The role of policies and socio economic factors. Land Use Policy, 46, 292-303. https://doi.org/10.1016/j.landusepol.2015.03.001

20. Wulandari, Y. A., Hartadi, R., \& Sunartomo, A. F. (2017). Analysis Of Factors Affecting Decisions Farmers Are Conversing Land And Fishings Impact On Farmers Revenues (Case Study of Wetland Rice Conversion in Kecamatan Kaliwates Kabupaten Jember ). Jurnal Agribest, 01(02), 152-167

21. Emerton, L., \& Snyder, K.A. (2018). Rethinking sustainable land management planning: Understanding the social and economic drivers of farmer decision-making in Africa. Land Use Policy, 79, 684-694. https://doi.org/10.1016/j.landusepol.2018.08.041

22. Chambers, R., Conway, G.R. (1991). Sustainable rural livelihoods: Practical concepts for the 21 st century. IDS Discussion Paper 296.

23. Dharmawan, A.H. (2007). Sistem penghidupan dan nafkah pedesaan. Sodality: Jurnal Sosiologi Pedesaan, 01(02), 169192.

24. Ellis F. (1999.) Rural Livelihood Diversity in Developing Countries: Evidence and Policy Implication.

25. Yulian, B.E., Dharmawan, A.H., Soetarto, E., \& Pacheco, P. (2018). Livelihood dilemma of the rural household around the oil palm plantation in East Kalimantan. Sodality: Jurnal Sosiologi Pedesaan, 5(3), 1-8.

26. Mudiarta, K.G. (2011). Perspektif dan peran sosiologi ekonomi dalam pembangunan ekonomi masyarakat. Forum Penelitian Ekonomi, Pusat Sosial Ekonomi dan Kebijakan Pertanian, 29(1), 55-66.

27. Andri, K.B. (2006). Perspektif pembangunan wilayah pedesaan. Inovasi, 6 (13).

28. Santika, T., Wilson, K.A., Meijaard, E., Budiharta, S., Law, E.E., Sabri, M., Poh, T. (2019). Land use policy changing landscapes, livelihoods and village welfare in the context of oil palm development. Land Use Policy, 87, 104073. https://doi.org/10.1016/j.landusepol.2019.104073

29. Sugiarto, T. (2003). Teknik Sampling. Gramedia. Jakarta

30. Roxborough, I. (1979). Theories of Underdevelopment (First Publ). Atlantic Highlands, New Jersey: Humanities Press Inc.

31. Mulyadi, M., Lestari, T.R.P., Alawiyah, F., Wahyuni, D., Astri, H., Martiany, D., \& Qodriyatun, S.N. (2015). Pembangunan berkelanjutan: dimensi sosial, ekonomi dan lingkungan. Jakarta: Pusat Pengkajian, Pengolahan Data dan Informasi (P3DI) Sekretariat Jenderal DPR RI dan Azza Grafika, Anggota IKAPI DIY.

32. Fauzi, A. (2014). Valuasi ekonomi dan penilaian kerusakan sumber daya alam dan lingkungan. IPB Pr, Bogor.

Cite this Article: Asnani, Arya Hadi Dharmawan, Bambang Juanda, Dudung Darusman (2021). The Contribution of Sugarcane Partnership for the Livelihood Structure and the Development of Rural Areas in Lampung Province of Indonesia. International Journal of Current Science Research and Review, 4(7), 667-676 